\title{
Lead Tolerance Profile of Pseudomonas Stuzeri in Liquid Culture
}

\author{
Su-Jung Kim, A-Young Jung ${ }^{1)}$, and Jin Ho Joo* \\ Department of Biological Environment, College of Agriculture and Life Sciences, \\ ${ }^{1)}$ graduate student, Department of Biological Environment, College of Agriculture and Life Sciences \\ Kangwon National University, Chunchon 200-701, Korea \\ (Received October 18, 2007, Accepted December 6, 2007)
}

\begin{abstract}
Pseudomonas stutzeri strain KCСM 34719 was used in this experiment to determine the effects of increasing $\mathrm{Pb}$ (II) concentrations on its growth rate. To obtain optimum growth conditions, strain KCCM 34719 was cultivated in nutrient broth under various conditions, such as temperature, $\mathrm{pH}$, and $\mathrm{NaCl}$ concentration. Optimal conditions for cell growth were $30{ }^{\circ} \mathrm{C}$ of temperature, $8.0 \mathrm{of} \mathrm{pH}$, and $3 \%$ of $\mathrm{NaCl}$ concentration, respectively. Growth response of bacterial cell to $\mathrm{Pb}$ (II) showed tolerance to concentrations ranging from 10 to $100 \mathrm{mg} I^{1}$ in liquid culture, following a growth pattem similar to the control. Growth rate was greatly inhibited at $200 \mathrm{mg} l^{1}$ of $\mathrm{Pb}(\mathrm{II})$.
\end{abstract}

Key Words: Heavy metals, Metal tolerance, Optimum conditions, Pseudomonas stutzeri

\section{INTRODUCTION}

Heavy metal pollution has raised concerns regarding the potential health risks to the public in the metal mining regions of South Korea. Biochemical acidgeneration processes in rocks and tailings exposed after mining are capable of dissolving heavy metals contained within the rocks and mine tailings ${ }^{1)}$. Heavy rainfall with combination of topological condition in South Korea can cause increasing mobilization of heavy metals, such as $\mathrm{Fe}, \mathrm{Al}, \mathrm{Mn}, \mathrm{Cu}, \mathrm{Pb}, \mathrm{Zn}, \mathrm{Cd}$, and $\mathrm{As}$, to paddy fields via surface and ground water, which the major crop, rice, is grown on. Furthermore, South Korea was reported as the second producer of $\mathrm{Cd}$ in $2005^{2}$. Most of the heavy metals are poisonous, causing severe dysfunction of the kidneys, reproductive system, liver, brain, and central nervous system ${ }^{3}$.

Physicochemical methods have been practiced for several decades for toxic heavy metal removal from industrial wastewaters. Although conventional sorption technology using chemical adsorbents has been exploited,

"Corresponding author:

Tel: +82-33-250-6448 Fax: +82-33-241-6640

E-mail: jhjoo@kangwon.ac.kr several disadvantages include both economic and environmental aspects ${ }^{4}$. Therefore, there is an urgent need for the development of cost-effective and efficient technologies that could treat metal-containing wastes including aqueous streams. A wide variety of living and dead biomass of bacteria, algae, fungi, and plants is capable of sequestering toxic metals from waste streams, which offers an economical alternative for sorption technologies. Once the toxic metals are absorbed and/or transferred within organic materials, they can be removed from wastewater and returned to the soil-organic matrix, which can enhance fixation of heavy metals in ecosystems ${ }^{5,6)}$.

The mechanisms associated with metal removal by microorganisms are rather complex compared with chemical absorbents, and can be divided into three categories: (1) biosorption of metal ions on the cell surface, (2) intracellular uptake of metal ions, and (3) chemical transformation of metal ions by microorganisms ${ }^{7}$. Adsorption of particulates has been observed with fungi and was proposed as a process for the removal of suspended matter from waste water ${ }^{8,9}$. The enhanced active uptake and intracellular deposition of metals has been reported for several elements like copper and iron $^{10)}$. In addition to the precipitation of metal 
hydroxidides by increased $\mathrm{pH}$, excess carbonate ions cause several heavy metals to precipitate as the respective metal carbonate according to simplified reaction: $\mathrm{Me}^{2+}+\mathrm{CO}_{3}{ }^{2-} \rightarrow \mathrm{MeCO}_{3}{ }^{11)}$. The capacity of any biosorbents is mainly influenced by biomass characteristics, physicochemical properties of the target metals, and the microenvironment of contact solution including $\mathrm{pH}$, temperature, and interaction with other ions ${ }^{12}$. For example, increase in $\mathrm{pH}$ can cause precipitation of metal ions generally in the order of $\mathrm{Fe}^{3+}>\mathrm{Cu}^{2+}>$ $\mathrm{Pb}^{2+}>\mathrm{Zn}^{2+}>\mathrm{Cd}^{2+}{ }^{4)}$.

Pseudomonas stutzeri is Gram-negative and aerobic and reside in soil and water ${ }^{13)}$. The living biomass has been found in mine waste waters polluted with various heavy metals and shown Cu-tolerant at a high concentration, $1000 \mathrm{mg} l^{-1}{ }^{14}$. The objective of this research was to determine the growth response of P. stutzeri strain KCCM 34719 to various conditions ( $\mathrm{NaCl}$ concentration, $\mathrm{pH}$, and temperature) in nutrient broth and to evaluate the optimum conditions for strain KCCM 34719 tolerant to $\mathrm{Pb}(\mathrm{II})$-containing broth.

\section{MATERIALS AND METHODS}

\section{Bacterial species and growth medium}

The microorganism used for this experiment was Pseudomonas stutzeri strain KCCM 34719 which was obtained from Korean Culture Center of Microorganism (KCCM), Seoul, Korea. Bacterial cell was initially cultured in nutrient broth (MERCK, Germany) and then maintained in nutrient agar medium (Difco, Detroit, USA). Cell density was determined by O.D. $600 \mathrm{~nm}$ with UV-vis spectrophotometer (SHIMADZU, Japan).

\section{Metal solution for growth response}

The nitrate salt of $\mathrm{Pb}$ (II) manufactured by Junsei, Japan, KANTO was used to prepare stock solution with autoclaved distilled water. The stock solution (1000 $\left.\mathrm{mg} l^{-1}\right)$ was diluted to a desired concentration with autoclaved distilled water before experiments.

\section{Response of Pseudomonas stutzeri to metal solution}

The nitrate salt of $\mathrm{Pb}(\mathrm{II})$ was added to a series of Erlenmeyer flasks containing Nutrient broth $(200 \mathrm{ml})$ with the following conditions: initial nitrate salt concentration $\left(10,50,100\right.$, and $\left.200 \mathrm{mg} t^{-1}\right), \mathrm{pH}(6.0$, 7.0, 8.0, and 9.0), temperature $\left(20,30\right.$, and $\left.38^{\circ} \mathrm{C}\right)$, and $\mathrm{NaCl}$ concentration $(0.5,1.0$, and $3.0 \%)$. In order to study the effect of the initial nitrate salt concentration, $\mathrm{pH}$, temperature, and $\mathrm{NaCl}$ concentration on the growth of strain KCCM 34719, the diluted broth suspension $(1 \mathrm{ml})$ was added to Nutrient broth with a given initial concentration and incubated at $\mathrm{pH} 8,30^{\circ} \mathrm{C}$, and $130 \mathrm{r} \mathrm{min}^{-1}$. Samples $(3 \mathrm{ml})$ were collected at selected time intervals for $240 \mathrm{~min}$ and analyzed for O.D. at $600 \mathrm{~nm}$.

\section{The mathematics of growth}

The rate of growth during the exponential phase in vitro culture can be expressed in terms of the average growth rate constant $(\mathrm{k})$.

$k=\left(\mathrm{N}_{\mathrm{t}}-\mathrm{N}_{0}\right) / \mathrm{t}$

where $N_{t}$ and $N_{0}$ is the O.D. values at time $t$ and initial time ${ }^{15)}$.

\section{RESULTS AND DISCUSSION}

\section{Optimum condition of Pseudomonas stutzeri}

Environmental temperature profoundly affects the growth rate of microorganisms, like all other organisms. Since $P$. stutzeri is Gram-negative, they are particularly susceptible. For these reasons, bacterial cell temperature directly reflects that of the cell's surroundings, which most influences enzyme-catalyzed reactions. When cells were grown in Nutrient broth with various temperatures, average growth of strain KCCM 34719 showed a longer lag phase at $20^{\circ} \mathrm{C}$ than at 30 and $38^{\circ} \mathrm{C}$ (Fig. 1); however, growth rate was highest at $30^{\circ} \mathrm{C}$ (Fig. 2).

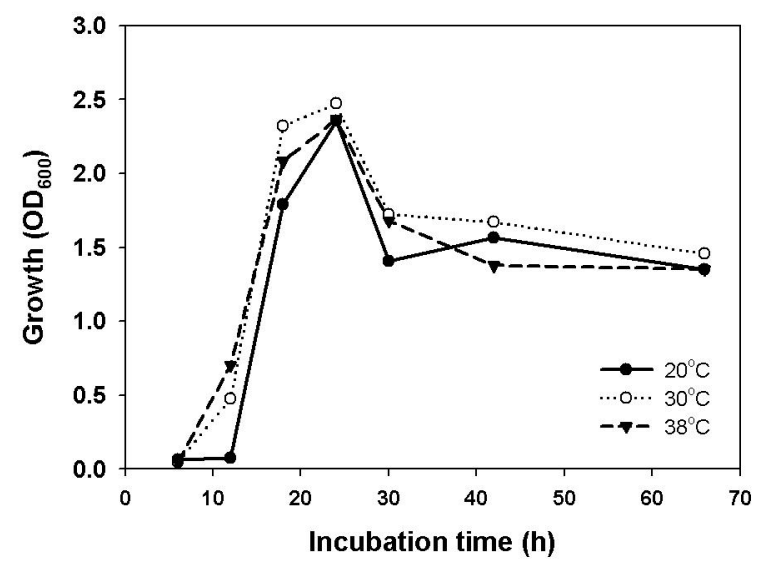

Fig. 1. Average growth of strain KCСM 34719 cultivated in nutrient broth containing $10 \mathrm{mg} l^{1}$ of $\mathrm{Pb}$ (II) at various temperatures over time (h). 


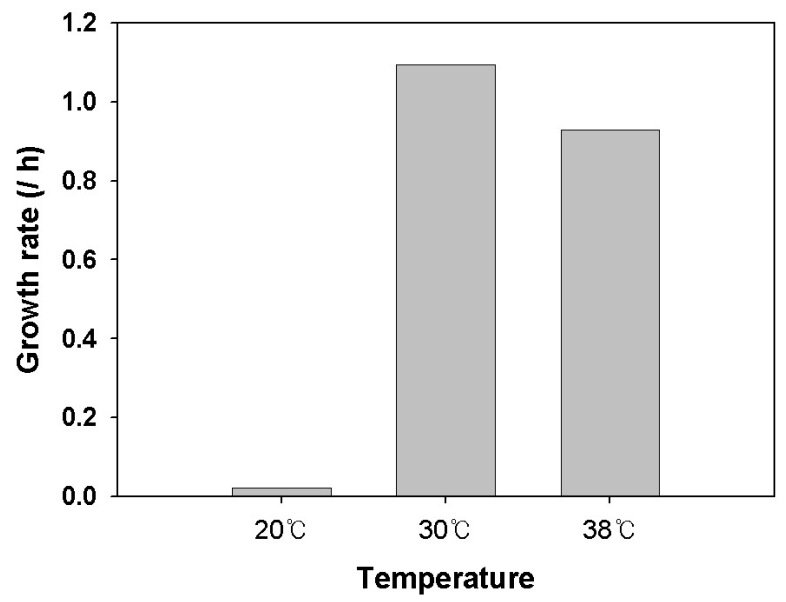

Fig. 2. The effect of temperature on averaged growth rate of strain KCCM 34719.

Microorganisms are dramatically influenced by $\mathrm{pH}$, each species of which has a definite $\mathrm{pH}$ growth range and growth optimal conditions. Although growth occurs over a wide range of $\mathrm{pH}$ and beyond the optima, there are limits to their tolerance. Drastic changes in cytoplasmic $\mathrm{pH}$ harm microorganisms by disrupting the plasma membrane or inhibiting the activity of enzymes and membrane transport proteins. It is well known that most bacteria die if the internal $\mathrm{pH}$ drops much below 5.0 to 5.5. We therefore conducted studies within a $\mathrm{pH}$ range from 6.0 to 9.0. Average growth of the bacterium over the $\mathrm{pH}$ ranges surprisingly followed similar lag phases (Fig. 3). However, growth rate was the optimum at $\mathrm{pH} 8.0$ (Fig. 4).

The amount of water available to microorganisms can be reduced by interaction with solute molecules known as the osmotic effect. Microorganisms differ greatly in their ability to adapt to habitats with low water activity $\left(a_{w}\right)$. Water activity is defined as $a_{w}=$ $\mathrm{P}_{\text {solu }} / \mathrm{P}_{\text {water }}$ where $\mathrm{P}_{\text {solu }}$ and $\mathrm{P}_{\text {water }}$ represent the vapor pressures of solution and pure water, respectively. Some microorganisms able to grow in a habitat with a low $a_{w}$ value are osmotolerant and may grow over a wide range of water activity or osmotic concentration. Halophiles especially can grow optimally in the presence of $\mathrm{NaCl}$ or other salts at the minimum concentration $2 \mathrm{M}^{15)}$. As shown in Figs. 5 and 6, strain KCCM 34719 was characteristically moderately halophilic. Average growth of strain KCCM 34719 in broth medium containing 3\% $\mathrm{NaCl}$ showed a longer lag phase than in the absence of $\mathrm{NaCl}$; strain $\mathrm{KCCM}$ 34719 could tolerate high levels of $\mathrm{NaCl}$ (Figs. 5 and 6).

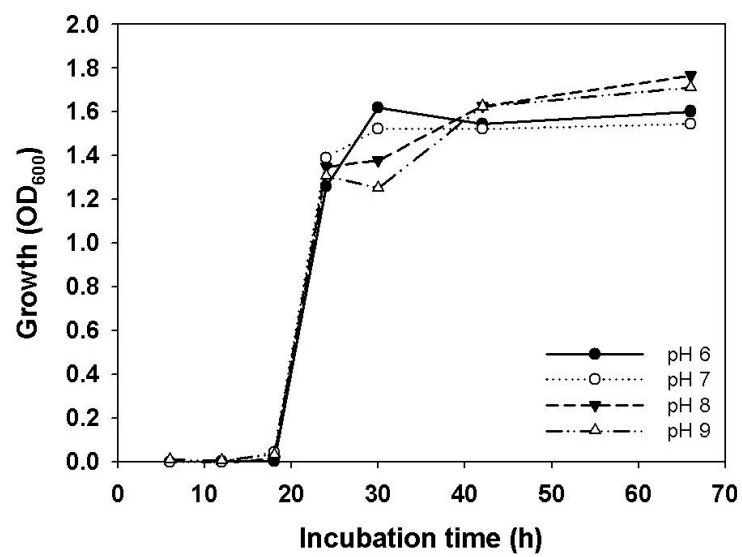

Fig. 3. Average growth of strain KCCM 34719 cultivated in nutrient broth containing $10 \mathrm{mg} I^{1}$ of $\mathrm{Pb}$ (II) at various pH over time (h).

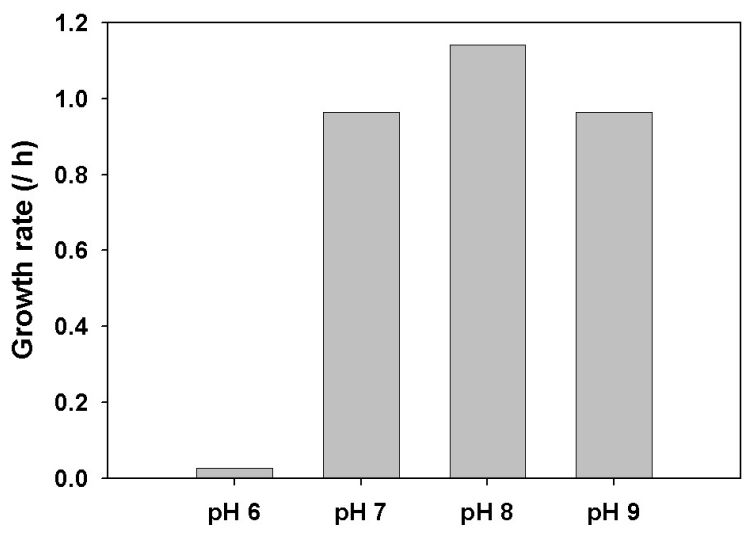

Fig. 4. The effect of $\mathrm{pH}$ on average growth rate of strain KCСM 34719.

Overall, strain KCCM 34719 had optimum conditions of $30^{\circ} \mathrm{C}$ of temperature, 8.0 of $\mathrm{pH}$, and $3 \%$ of $\mathrm{NaCl}$ in broth medium containing $10 \mathrm{mg} l^{-1}$ of $\mathrm{Pb}(\mathrm{II})$, which in turn has been known to affect tolerance capacity (or sorption capacity) of the strain to heavy metals at a higher concentration ${ }^{16,17)}$.

\section{Growth response of strain KCCM 34719 to $\mathrm{Pb}$ (II)}

Growth response of strain KCCM 34719 in liquid culture from 10 to $100 \mathrm{mg} l^{-1}$ conc. of $\mathrm{Pb}(\mathrm{II})$ followed the same growth pattern as the control for $66 \mathrm{~h}$ incubation (Fig. 7). Growth curve of the bacterium in the broth containing $200 \mathrm{mg} l^{-1}$ of $\mathrm{Pb}(\mathrm{II})$ showed a much longer lag phase than any other conditions, meaning that the growth was greatly inhibited at 200 $\mathrm{mg} l^{-1}$ of $\mathrm{Pb}$ (II). Since most metal-microbe interactions are initiated at the concentration level of metal uptake by microorganisms, the uptake mechanism is 


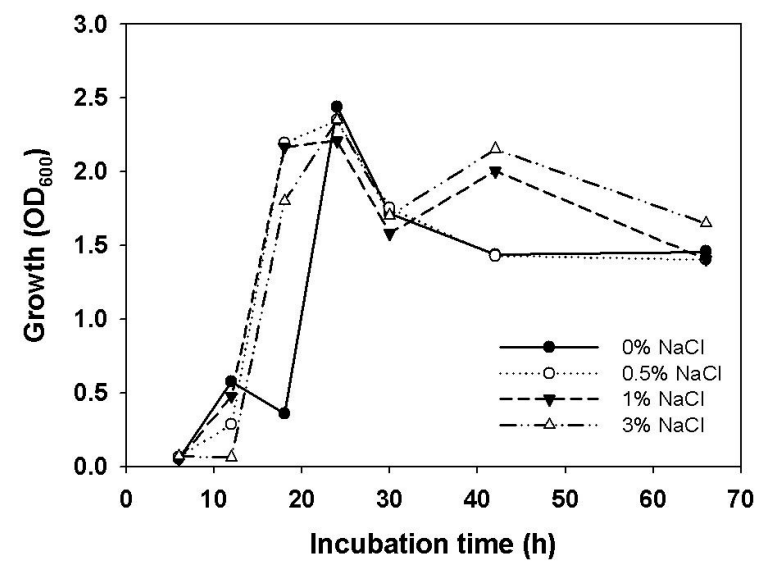

Fig. 5. Average growth of strain KCСM 34719 cultivated in nutrient broth containing $10 \mathrm{mg} l^{1}$ of $\mathrm{Pb}$ (II) at various $\mathrm{NaCl}$ concentrations over time (h).

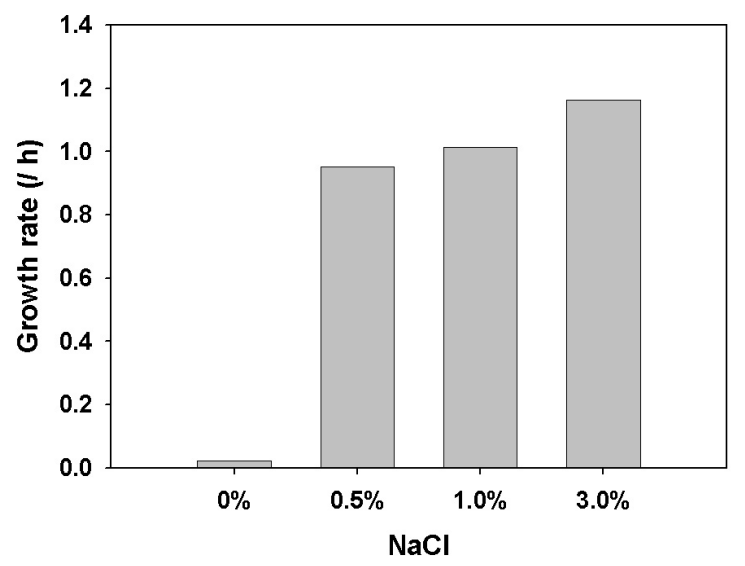

Fig. 6. The effect of $\mathrm{NaCl}$ concentration on average growth rate of strain KCCM 34719.

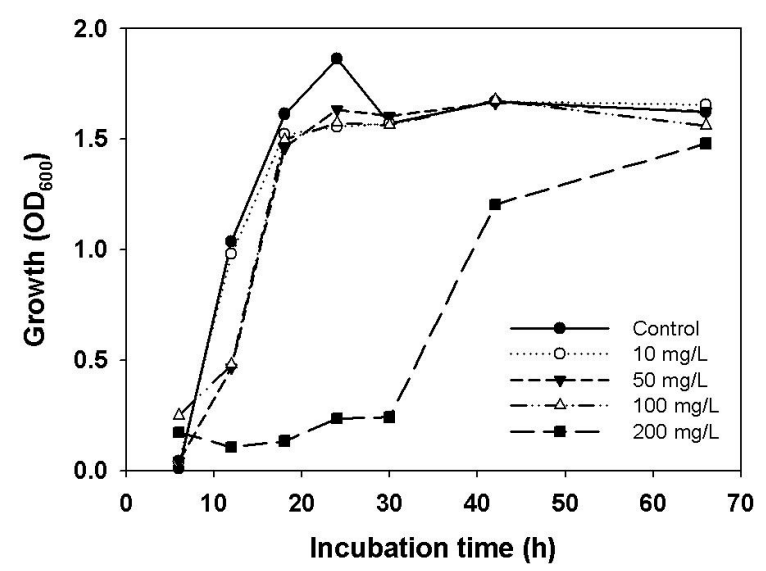

Fig. 7. Average growth of strain KCCM 34719 cultivated at various $\mathrm{Pb}$ (II) concentrations over time (h).

likely to be linked to the mechanism of metal resistance in the microorganism ${ }^{4,17,18)}$. Strain KCCM 34719, thus, may be capable of removing significant concentrations of $\mathrm{Pb}(\mathrm{II})$ during the active growth cycle.

\section{ACKNOWLEDGEMENT}

This study was supported by a grant from the Research Institute of Agricultural Science, Kangwon National University, Korea.

\section{REFERENCES}

1. Sengupta, M. (1993) Environmental impacts of mining: monitoring, restoration, and control. CRC Press, Boca Raton, FL, USA. pp. 167-259.

2. British geological survey. (2006) Annual report of the British geological survey 2005-2006. Natural Environment Research Council. The United Kingdom of Great Britain. www.bgs.ac.uk/ annualreport/ 0506

3. Adriano, D. C., Bollag, J. -M., Frankenberger, W. T. Jr. and Sims, R. C. (1999) Bioremediation of contaminated soils. ASA-CSA-SSSA, Madison, WI, USA. pp. 53-88.

4. Eccles, H. (1999) Treatment of metal-contaminated wastes: why select a biological process? T. Biotech. 17, 462-165.

5. Paul, E. A. (2007) Soil microbiology, ecology, and biochemistry. Elsevier Inc., Burlington, MA, USA. pp. 389-432.

6. Hughes, M. N. and Poole, R. K. (1989) Metals and microorganisms. Chapman \& Hall, New York, USA. p 412.

7. Harbhajan, S. (2006) Mycoremediation: fungal bioremediation. John Wiley \& Sons, Inc., Hoboken, NJ. USA. pp. 484-532.

8. Amils, R. and Ballester, A. (1999) Biohydrometallurgy and the environment toward the mining of the 21st century. Part B. Elsevier, Amsterdam. pp. 725-730.

9. Poole, R. K. and Gadd, G. M. (1989) Metal- microbe interactions. Special publications of the society for general microbiology. Volume 26. IRL Press, Oxford. pp. 119-130.

10. Poole, R. K. and Gadd, G. M. (1989) Metal- microbe interactions. Special publications of the society for general microbiology. Volume 26. IRL Press, Oxford. pp. 85-98.

11. Laskin, A. I., Bennett, J. W. and Geoffrey, G. (2001) 
Advances in applied microbiology. Academic Press, San Diego. pp. 135-169.

12. Chen, C. and Wang, J. (2007) Influence of metal ionic characteristics on their biosorpiton capacity by Saccharomyces cerevisiae. Appl. Microbiol. Biotechnol. 74, 911-917.

13. Singleton, P. and Sainsbury, D. (1987) Dictionary of microbiology and molecular biology. John Wiley \& Sons Ltd., New York, NY, USA. p. 721.

14. Cho, J.-S., Han, M.-G., Lee, H.-J. and Heo, J.-S. (1997) Copper accumulation in cells of copper- tolerant bacteria, Pseudomonas stutzeri. Korean J. Environ. Agric. 16, 48-54.
15. Prescott, L. M., Harley, J. P. and Klein, D. A. (2005) Microbiology. McGraw-Hill, New York, NY, USA. pp. 109-132.

16. Sparks, D. L. (2003) Environmental soil chemistry. Academic Press. San Diego, CA, USA. pp.133-185.

17. White, C., Wilkinson, S. C. and Gadd, G. M. (1995) The role of microorganisms in biosorption of toxic metals and radionuclides. Int. Biodeter. Biodegradation. 36, 17-40.

18. Yilmaz, E. I. (2003) Metal tolerance and biosorption capacity of Bacillus circulans strain EB1. Res. Microbio. 154, 409-415. 